\title{
First Record of an Anomalous Catla catla (Ham. Buch) in Fresh Water Fish Ponds of Gurdaspur District, Punjab (India)
}

\section{Wani MA ${ }^{1}$, Dutta SPS ${ }^{2 *}$}

${ }^{1}$ Department of Environmental Sciences and Limnology, Barkatullah University, Bhopal, Madhya Pradesh, India ${ }^{2}$ Department of Environmental Sciences, University of Jammu, Jammu, Jammu and Kashmir, India

\begin{abstract}
Multiple morphological and vertebral deformities (ankylosis, kyphosis and scoliosis) in two adult specimens of Catla catla (Ham. Buch) from fresh water fish ponds of Punjab are reported for the first time. Degradation of water caused by pesticides is most probably the cause of such fish anomalies.
\end{abstract}

Keywords: Morphological and skeletal deformities; Catla catla; Environmental degradation; Punjab fish ponds

\section{Introduction}

Since the pioneering report of deformed Catla catla by Hora [1] and Law [2] there have been a few records of deformities by Bhattacharya [3], Pillai and Thampy [4] for this fish from Indian waters. In Punjab state, where there is extensive fish culture in fish ponds, there is no work available on teratology of Catla catla. In this communication morphological and skeletal deformities observed in two adult specimens of this fish are described for the first time.

\section{Materials and Methods}

Two deformed specimens of Catla catla, cultured and imported from Gurdaspur fish ponds, Punjab, were purchased at Gumat fish market, Jammu, and studied for morphological characteristics, morphometric examination and radiological examination (Fuji green base film with SEMIN $100 \mathrm{MA}$, X-ray machine, at 10 millions and 50 $\mathrm{KV}$ for $0.25 \mathrm{sec}$.)

\section{Observations}

Two aberrant specimens of Catla catla (Ham. Buch) seen along with normal fish specimens are described as under:

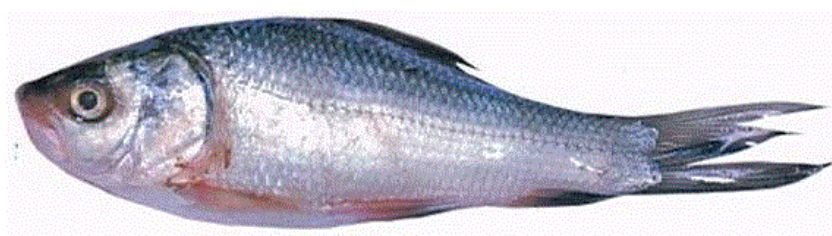

Figure 1a: Normal specimen of Catla catla. (Ham.Buch).

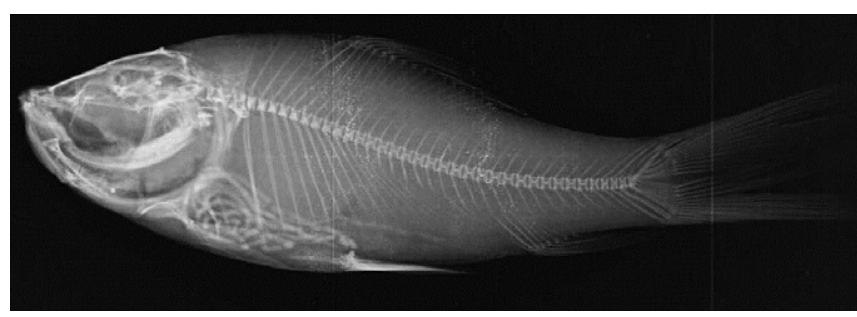

Figure 1b: X-ray photograph of normal specimen of Catla catla (Ham. Buch).

\section{Catla catla (Ham. Buch) showing post dorsal depression and} disposition of fins

Measuring $44.8 \mathrm{~cm}$ and weighing $951 \mathrm{~g}$, this aberrant adult specimen of Catla catla (Ham. Buch) was identified by post dorsal depression and disposition of fins. Like a normal fish, the dorsal fin placement is more towards the caudal fin base than the snout tip. In this aberrant fish, pectorals extend pelvics base, pelvics extend almost the anal fin base and the latter extends beyond the caudal fin base. Contrary to this, in a normal fish the longest pectoral fin ray falls short of pelvic fin origin, longest pelvic fin ray falls short of anal fin base and longest anal fin ray falls short of caudal fin base. The caudal fin is bilobed. Like a normal fish, number of lateral line scales are 42 in this deformed specimen. Body scales in post dorsal region are, however, short and overlapping (Figure 1a).

$\mathrm{X}$-ray analysis of normal fish reveals a stream lined vertebral column having 35 normal amphicoelous vertebrae (Figure 1b). There are 34 amphicoelous vertebrae in this deformed fish (Figure 2a). Some deformities in the vertebral column placement and vertebral structure in this aberrant fish are given as under:

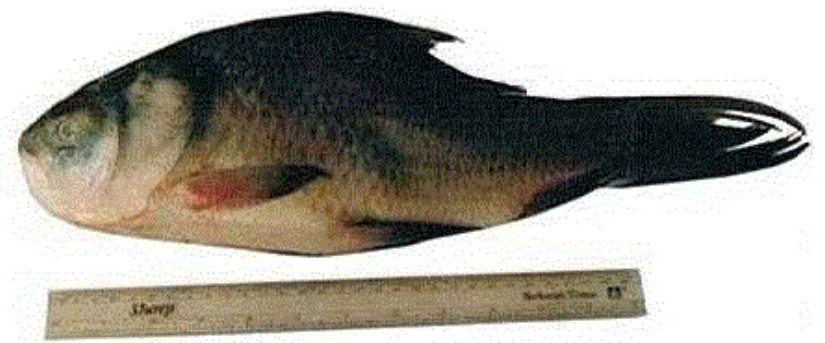

Figure 2a:Catla catla (Ham. Buch) Showing post dorsal depression and disposition of fins.

*Corresponding author: Dutta SPS, Department of Environmental Sciences, University of Jammu, Jammu-180004, Jammu and Kashmir, India; Tel: 01912431365; E-mail: duttasps@gmail.com

Received February 13, 2014; Accepted May 08, 2014; Published July 20, 2014

Citation: Wani MA, Dutta SPS (2014) First Record of an Anomalous Catla catla (Ham. Buch) in Fresh Water Fish Ponds of Gurdaspur District, Punjab (India). J Aquac Res Development 5: 246 doi:10.4172/2155-9546.1000246

Copyright: $\odot 2014$ Wani MA, et al. This is an open-access article distributed under the terms of the Creative Commons Attribution License, which permits unrestricted use, distribution, and reproduction in any medium, provided the original author and source are credited. 
Citation: Wani MA, Dutta SPS (2014) First Record of an Anomalous Catla catla (Ham. Buch) in Fresh Water Fish Ponds of Gurdaspur District, Punjab (India). J Aquac Res Development 5: 246 doi:10.4172/2155-9546.1000246

Page 2 of 4

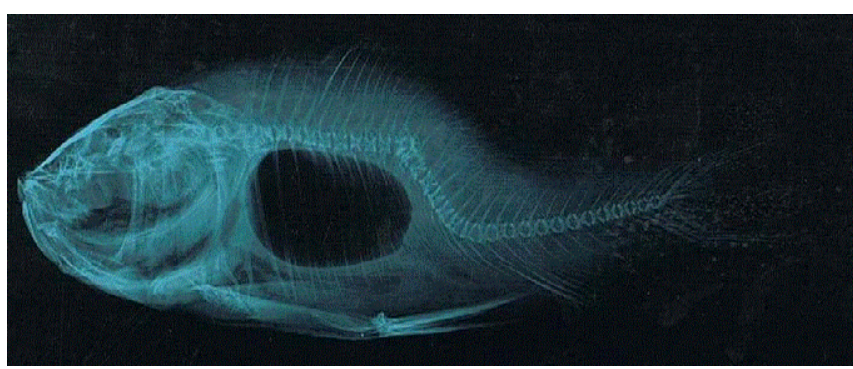

Figure 2b: X-ray photograph of Catlacatla (Ham. Buch) Showing post dorsal depression and disposition of fins.

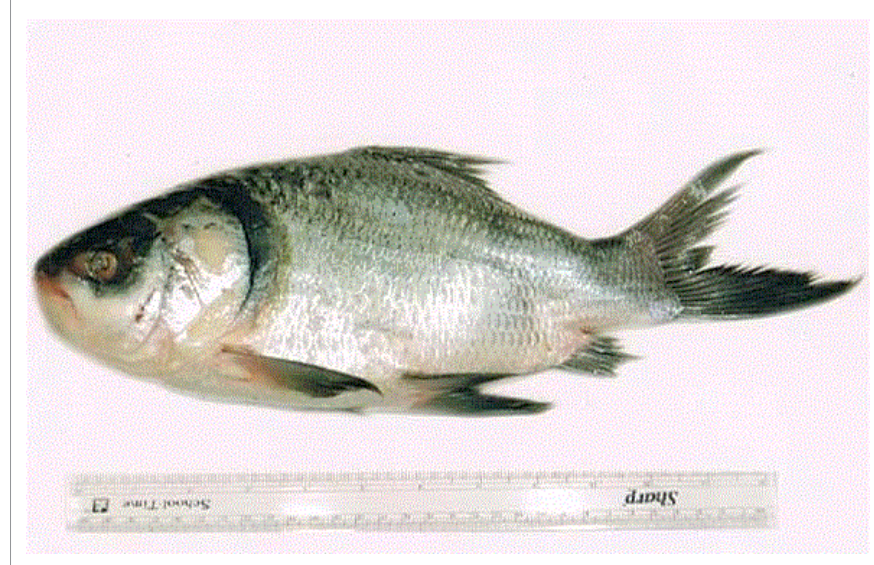

Figure 3a: Catla catla (Ham. Buch) Showing abnormal body height, highly truncated post dorsal body and disposition of fins.

- Placement of vertebral column between $1^{\text {st }}$ to $10^{\text {th }}$ vertebrae, after the complex vertebrae, is like a normal fish.

- Between $11^{\text {th }}$ to $22^{\text {nd }}$ vertebrae, vertebral column is directed downwards producing a shallow $\mathrm{V}$ shaped structure (lordosis) with normal posterior vertebral column. $11^{\text {th }}$ and $16^{\text {th }}$ vertebrae undifferentiated and $13^{\text {th }}$ to $16^{\text {th }}$ vertebrae opaque (ankylosis).

- Vertebral column between $19^{\text {th }}$ to $34^{\text {th }}$ vertebrae normal.

- Urostyle and caudal bones are normal.

In this aberrant fish, unlike bilobed airbladder in a normal fish (Figure $1 \mathrm{~b}$ ) anterior lobe is normal and posterior lobe is rudimentary (Figure 2b).

From X-ray analysis it is clear that curved post dorsal body is caused by lordosis and undifferentiated $11^{\text {th }}$ to $16^{\text {th }}$ vertebrae.

\section{Catla catla (Ham. Buch) showing abnormal height, highly truncated post dorsal body and disposition of fins}

This aberrant specimen of Catla catla (Ham.Buch), measuring $42 \mathrm{~cm}$ and weighing $900 \mathrm{~g}$,was recognized by multiple aberrations viz. abnormal body height, highly truncated post dorsal body and disposition of paired viz. pectoral and pelvic and unpaired fins viz. dorsal and anal (Figure 3a). Dorsal fin placement is like a normal fish. In a normal fish, there is a wide space between the tip of the longest pectoral fin ray and the pelvic fin origin, tip of the longest pelvic fin ray and the anal fins origin and tip of the longest anal fin ray and the caudal fin base. In this abnormal fish, pectorals extend pelvics base, pelvics extend almost the anal fin base and the latter extends beyond the caudal fin base. Lateral line scales are 42 in both normal and abnormal fish. Lateral line in this deformed fish is irregular in the post dorsal region. Body scales in post dorsal region are short and overlapping.

Like a normal fish, as reveal by the X-ray, there are 35 amphicoelous vertebrae in the vertebral column. (Figure $1 \mathrm{~b}$ and Figure $3 \mathrm{~b}$ ). There are some deformities in the vertebral column placement and vertebral structure in this deformed fish and are given as under:-

- Placement of vertebral column and vertebral structure between $1^{\text {st }}$ to $12^{\text {th }}$ vertebrae, after the complex vertebrae, is normal.

- Between $12^{\text {th }}$ to $35^{\text {th }}$ vertebrae, vertebral column is irregular having dome, trough, (kyphosis) and a semilunar shape and is elaborated as under:-

Vertebral column between $12^{\text {th }}$ to $18^{\text {th }}$ vertebrae forms a dome (kyphosis) in which:

- Vertebral column between $12^{\text {th }}$ and $13^{\text {th }}$ vertebrae forms the anterior side of the dome. Vertebral thickness and inter vertebral spaces reduced.

- Vertebral column between $14^{\text {th }}$ to $16^{\text {th }}$ vertebrae forms the roof of the dome. Vertebral thickness and intervertebral spaces reduced.

- Vertebral column between $17^{\text {th }}$ to $18^{\text {th }}$ vertebrae represents the posterior side of the dome. Intervertebral spaces not clear.

Vertebral column between $17^{\text {th }}$ to $25^{\text {th }}$ vertebrae, along with the posterior side of anterior dome, forms a trough (lordosis) in which:

- Vertebral column between $17^{\text {th }}$ to $19^{\text {th }}$ vertebrae represents anterior side of trough. Vertebrae short and intervertebral thickness not clear.

- Vertebral column between $20^{\text {th }}$ and $22^{\text {nd }}$ vertebrae represents the semicircular base of trough. Vertebral thickness reduced and intervertebral spaces not clear.

- Vertebral column between $23^{\text {rd }}$ to $25^{\text {th }}$ vertebrae forms the posterior side of the trough. Vertebral thickness reduced and intervertebral spaces not clear.

Vertebral column between $24^{\text {th }}$ to $30^{\text {th }}$ vertebrae, along with posterior side of trough, forms (kyphosis) in which:

- $24^{\text {th }}$ to $26^{\text {th }}$ vertebrae represent anterior side.

- $27^{\text {th }}$ and $28^{\text {th }}$ vertebrae form angle. Vertebral thickness reduced and intervertebral spaces not clear.

- $29^{\text {th }}$ and $30^{\text {th }}$ vertebrae, having reduced intervertebral spaces,

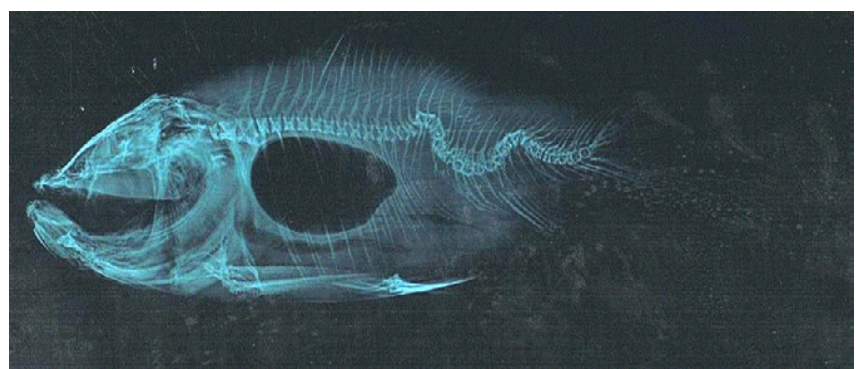

Figure 3b: X-ray photograph of Catla catla (Ham. Buch.) Showing abnormal body height, highly truncated post dorsal body and disposition of fins. 
represent posterior side. Haemal spines of $28^{\text {th }}$ to $29^{\text {th }}$ vertebrae are fused.

- Vertebral column between $31^{\text {st }}$ to $35^{\text {th }}$ vertebrae forms a semilunar shape. Intervertebral spaces not clear.

\section{Water degradation by pesticides}

In a normal fish air bladder has two lobes viz. anterior large lobe and posterior elongated lobe. In this aberrant fish, on the other hand, anterior lobe is normal and posterior lobe is highly degenerated (Figure $1 \mathrm{~b}$ and Figure $3 \mathrm{~b})$.

From radiological analysis it is clear that truncated post dorsal body is caused by post dorsal irregular vertebral column between $12^{\text {th }}$ to $35^{\text {th }}$ vertebrae having dome, a trough, (kyphosis) and a semilunar shape in caudal peduncle region.

Pesticides, the foremost efficient suggests that of tormenter and weed management, enable the upkeep of current yields and then contribute to economic viability. Concern regarding the environmental impact of continual chemical use has prompted analysis into the environmental fate of those agents, which might migrate from treated fields to air, alternative land and water bodies. However long the chemical remains within the soil depends on however powerfully it's sure by soil parts and the way pronto it's degraded. It conjointly depends on the environmental conditions at the time of application, e.g., soil water content. Chemical use should guarantee public safety and environmental protection with regards to each the chemical itself and their doubtless harmful metabolites. This paper reviews what's celebrated of the influence of the physical and chemical characteristics of the soil system, like wet content, organic matter and clay contents, and $\mathrm{pH}$, on the sorption/desorption and degradation of pesticides and their access to groundwater and surface waters. AN understanding of the fate of pesticides is crucial for rational decision-taking relating to their authorization. To achieve AN adequate understanding would require the concourse of soil science, clay geology, chemical science, surface chemistry, environmental biology, plant physiology and, no doubt, alternative disciplines. Solely through a multidisciplinary approach to environmental analysis can or not it's attainable to set up, manage, pursue and integrate the results of the studies which will be necessary for the event of tools and techniques permitting effective environmental decision-making. There appears to be a good potential to develop microbially derived pesticides, that square measure effective, reliable and have an occasional environmental risk. additionally, new application techniques, as an example exactitude band spraying, will scale back the dose, which might be a awfully effective thanks to minimize transport and emission however conjointly to avoid a buildup of resistance in target organisms. Improved formulations also will be required to scale back off-target deposition, improve retention heading in the right direction, and enhance uptake and translocation.

To determine the cause of the fish die-off, the researchers collected water and fish samples immediately following the chemical release in 2007. The samples analyses and results clearly showed that the hydraulic fracturing fluids degraded water quality in Acorn Fork, to the point that the fish developed gill lesions, and suffered liver and spleen damage as well.

After the fracturing fluids entered Acorn Fork Creek, the water's $\mathrm{pH}$ dropped from 7.5 to 5.6 , and stream conductivity increased from 200 to 35,000 microsiemens per centimeter. A low $\mathrm{pH}$ number indicates that the creek had become more acidic, and the stream conductivity indicated that there were higher levels of dissolved elements including iron and aluminum.

\section{Discussion}

Fish anomalies have been attributed to:

- $\quad$ Physical factors like temperature [5-7] and currents [8,9]; chemical factors viz. salinity fluctuations $[6,10,11]$ and low dissolved oxygen and high free $\mathrm{CO}_{2}[7,12,13]$ environmental degradation [1420] biological factors like predation/injury [19-23], parasitic infestation $[24,25]$, nutritional imbalance [11,26-29] hereditary [14,30,31] and inbreeding and dense stocking rate [32-35].

In Punjab state, a leading grain producing state, there is indiscriminate use of pesticides and fertilizers and is resulting in degradation of the surface and ground waters. Thus, anomalies in Catla catla, under discussion, are most probably caused by water degradation and are in agreement to the observations of Al-Harbi, Cheng, Yershow Jawad, Olantunji Akioye, Gupta \& Dutta [14-19]. However, a detailed analysis of these abiotic and biotic factors is required before any conclusion is drawn about the possible cause of fish anomalies.

\section{References}

1. Hora SL (1942), A hump backed Catla catla Proc Royal Asiatic Society.

2. Law NC (1944) A hump backed carp, Catla catla Proc Nat Inst Sci 10: 97-103.

3. Bhattacharyan S (1983) Abnormal silver carps, Hypophthalmiethys molitrix, in fish nurseries. Environ Ecol 1: 15-16.

4. Pilli CT, Thampy DM (1990) Cases of deformities in some cultivable fishes. Indian J Fish 37: 171-173.

5. Wiegand MD, Hataley JM, Kitchen CL, Buchanan LG (1989) Induction of developmental abnormalities in larval (Carrassius auratus) under cool incubation conditions. J Fish Biol 35: 85-95.

6. Silverstone AM, Hammell L (2002) Spinal deformities in farmed Atlantic salman Can vet J 43: 782-784.

7. Amitabh H, Firoz AM (2010) A wild specimen of Indian carp, Cirrhinus mrigala (Ham) 1822 with multiple vertebral deformities. World J Zoology 5: 167-177.

8. Hilger I (1992) Spinal compression of Altantic cod, Gadus morhua, from Wadden Sea Dis Aquatic Org 13: 83-88.

9. Chatian B (1994) Abnormal swim bladder and lordosis in sea bass (Dicentrachus lubrase) and seabream, (Sparus auratus) Aquaculture 119: 371-379.

10. Johanson DW, Katavic I (1984) Mortality, growth and swim bladder stress syndrome of sea bass (Dicentrarchus labrase) larvae under varied environmental conditions. Aquaculture 38: 67-78.

11. Jawad LA, Oktener A (2007) Incidence of lordosis in the fresh water mullet Liza abu (Heckel, 1843) collected from Ataturk dam lake, Turkey. Anales de Biologia 29: 105-113.

12. Al-Hassan LAJ (1992) Vertebral deformities in fishes from Iraq and united Arab Emirates. Arabian Gulf Irqi Jour Mar Sci 1: 13-23.

13. Martens LG, Witten PE, Fivelsted A. Huysseune S, Salvaried B, Vikesa V et al. (2006) Impact of high water carbon dioxide on Atlantic salmon smelts (Salmo salar L.) on fish performance, vertebral composition and structure. Aquaculture 261: 80-88.

14. Al-Harbi AH (2001) Skeletal deformities in cultured common carp, Cyprinus carpio L Asian Fisheries Science 14: 247-254.

15. Cheng SH, Kong W, Wing A, Shiv R (2006) Six different types of deformities in zebra fish embryo's due to cadmium.

16. Yershow PN (2008) The vertebral abnormalities in eel-pout, Zoraces viviparous (Linneous 1758), (Pisces Zoarcidae) Proceedings of the Zool 312: 74-82.

17. Jawad LA, Sadighzadeh Z, Vallinassab T (2010) Malformation of the caudal fin in the fresh water mullet, Liza abu (Actiropterygii:Mugilidae), collected from Karkhe river, Iran. Analas de Biologia 32: 11-14. 
Citation: Wani MA, Dutta SPS (2014) First Record of an Anomalous Catla catla (Ham. Buch) in Fresh Water Fish Ponds of Gurdaspur District, Punjab (India). J Aquac Res Development 5: 246 doi:10.4172/2155-9546.1000246

18. Olantunji-Akioye AO, Adeyemo OK, Akomolafe OT (2010) Photographic and radiographic study of osteological abnormalities of the head of adult African catfish.(Clarias gariepinus). Int J Monphol 28: 719-722.

19. Gupta N, KN Ali, Dutta SPS (2010) Morphological and skeletal deformities in two specimens of Clarias batrachus (Linneaus) from fresh water ponds of Punjab, India, J Aqua Biol 25: 219-222.

20. Dutta SPS, Salathia D, Chander G, Kumar H (2011) Anomalies in Cirrhinus mrigala, a commercially important fresh water food fish, from Gurdaspur district of Punjab. The Bioscan 6: 405-411.

21. Devadoss $P$ (1983-84) on some specimens of abnormal Elasmobranchs. Matsya 9 and 10: 186-188.

22. Srivastava AK (1983-84) Caudal fin deformity in a fresh water spiny eel Macrognathus aculeatus.Matsya, 9 and 10: 189-190.

23. Dutta SPS, Kumar S (1991) Deformity in dorsal fin in Puntius conchonius (Ham.) from Jammu Geobios new Reports 5: 173-174.

24. Kent ML, Watral VG, Whipps CM, Cunningham ME, Criscione CD, et al, (2004) A digenean metacescariae (Apophallus spp.) and a Myxozoan (Myxobollus spp.) associated with vertebral deformities in cyprinid fishes from the Williamette river Oregon J Aquat Anim Health 16:116-129.

25. Yokoyama HMA, Freeman N, Itoh, Fukuda Y (2005) Spinal curvature of cultured Japanese mackerel, Scomber japanicus, associated with a brain Myxospordian, Myxobolus acanthogobii. Dis Aquat Org 66: 1-7.

26. Gavaia PJ, Dinis MT, Cancela ML (2002) Oestological development and abnormalities of vertebral column and caudal skeleton in larval and juvenile stages of hatchery raised Senegal sole (Sole Senegalensis). Aquaculture 211: 305-323.

27. Cahu C, Infaute JZ, Takeuchi T (2003) Nutritional components affecting skeletal development in fish larvae-Aquaculture 227: 245-258.

28. Lall SP, Lewis-McCrea LM (2007) Role of nutrients in skeletal metabolism pathology in fish, an overview Aquaculture 267: 3-19.

29. Omotayo F, Abayomi OJ (2011) skeletal malformation among the Clarias species from fish mongers in Ekiti State. Continental J Fisheries and Aquatic Science 5: 32-37.

30. Lagardere F, Bulhic T, Bueron T (1993) Anomalies in cephalic area in laboratory reared larvae and juveniles of Solea solea. Fish Biol 36: 35-46.

31. Sadler J, Pankhurst PM, King HR (2001) High prevalence of skeleta deformities and reduced gill surface area in triploid Atlantic salmon (Salmon salar). Aquaculture 198: 369-386.

32. Aulstad D, Kittelsen A (1971) Abnormal body curvatures of rainbow trout (Salmo gairdneri) inbred fry J Fish Res Bd Can 28: 1918-1920.

33. WohIFarth WS, Maov R (1971). Genetic investigation and breeding method of carp in Israel Rep. FAO/UNDP (TA) 2926: 160-185.

34. Piron RD (1978) Spontaneous skeletal deformities in the zebra danio(Brachidanio rerio) bred for fish toxicity tests. J Fish Biol 13: 79-83

35. Vigsholm J, Djupvik HO (1998) Risk factor for spinal deformities in Salmon J Fish Diseases 21: 47-53. 